Scelidosaurus, a form with some features pointing strongly towards the Ornithopoda.

The Carnivorous Dinosauria now best known may all be placed at present in a single order, and this is widely separated from those that include the herbivorous forms. The two sub-orders defined include very aberrant forms, which show many points of resemblance to Mesozoic birds. Among the more fragmentary remains belonging in this order, but not included in the present classification, this resemblance appears to be carried much farther.

The order Hallopoda, which I have here referred to the Dinosauria, with doubt, differs from all the known members of that group in having the hind feet specially adapted for leaping, the metatarsals being half as long as the tibia, and the calcaneum produced far backward. This difference in the tarsus, however, is not greater than may be found in a single order of Mammals, and is no more than might be expected in a sub-class of Reptiles.

Among the families included in the present classification, I have retained three named by Huxley (Scelidosaurida, Iguanodontida, and Megalosaurida), ${ }^{x}$ although their limits as here defined are somewhat different from those first given. The sub-order Compsognatha, also, was established by that author in the same memoir, which contains all the more important facts then known in regard to the Dinosauria. With the exception of the Hadrosaurida, named by Cope, the other families above described were established by the writer.

The Amphisauride and the Zanclodontida, the most generalised families of the Dinosauria, are only known from the Trias. The genus Dystrophaus, referred provisionally to the Sauropoda, is likewise from deposits of that age. The typical genera, however, of all the orders and sub-orders are Jurassic forms, and on these especially the present classification is based. The Hadrosaurida are the only family confined to the Cretaceous. Above this formation, there appears to be at present no satisfactory evidence of the existence of any Dinosauria.

\section{THE TAY AND THE FORTH BRIDGES}

THE reconstruction of the Tay Bridge (if it really go on) by Mr. W. H. Barlow and the re-designing of the Forth Bridge by Mr. John Fowler and Mr. B. Baker will undoubtedly mark a new point of departure in the practice of British engineers. With the advent of railways there arose a generation of engineers who for some inexplicable reason ignored the traditions of their predecessors and gave no thought to wind pressure. Previous to this the question was always considered of vital importance by constructors. For example, Tredgold, writing some sixty years ago about roofs over building slips, directed special attention to the fact that such structures were "much exposed to be racked and strained by high winds," and recommended certain proportions, based upon the assumption of the actual weight of the roof being $16 \mathrm{lbs}$. per square foot, and the pressure of the wind 40 lbs. per foot. $\mathrm{He}$ thus clearly warned engineers that in some instances the pressure of the wind and not the load governs the strength of the structure. Nevertheless so completely have British engineers ignored this condition that it may safely be said at least three-fourths of the railway bridges in Great Britain and Ireland have no lateral bracing or provision of any kind to enable them to resist wind pressure. Even metallic arched bridges, which from their form must, in the absence of cross bracing, be necessarily in a state of more or less unstable equilibrium, form no exception to the rule. At Richmond, for instance, and at Kingston also, there are cast-iron arches about Ioo feet in span, the lateral stability of which is dependent solely upon the 8 inches or ro inches wide flanges of the arched ribs. There is no lateral bracing nor are there any iron cross- girders to bind the arched ribs together, and the lateral stiffness of a Io-inch flange over a span of Ioo feet is more easily imagined than calculated. Within a few hundred yards of the Richmond Bridge is an anemometer which, according to the official returns, has not infrequently recorded a pressure of $27 \mathrm{lbs}$. per square foot, but it is hardly necessary to say that no wind pressure even approximating to that amount could ever have taken effect on the bridge.

Since the fall of the Tay Bridge the principles and practice of Telford's day have been reverted to by British engineers, and the question of wind pressure has been most influential in determining the design and proportions of the new Tay and the proposed Forth Bridges.

In the original Tay Bridge the type of pier foundation finally developed was, it may be remembered, a single cylinder of $3 \mathrm{I}$ feet diameter. This was satisfactory enough as regards vertical pressure, but in the new design it was lateral and not vertical pressure which governed the form of the pier's foundation, and the latter will consist not of a single 31 feet cylinder but of two 23 feet cylinders spread 32 feet apart centre to centre, and affording correspondingly increased lateral stability. Similarly, as regards the metallic piers resting on these foundations : originally these consisted of a group of cast iron columns, and as regards vertical pressure nothing could be better, for, as we have recently ascertained by tests, a hollow cast-iron column of ordinary proportions will carry more load than either a wrought iron or a steel tube of equal weight. When the bending action of the wind upon a bridge pier is taken into consideration, however, the steady vertical pressure due to the load becomes of comparatively little moment, and Mr. Barlow has very properly adopted wrought iron for the piers of the new Tay Bridge, and the Board of Trade have with no less propriety intimated, in their recent "Memorandum of Requirements," that piers made up of a group of small cast-iron columns will no longer be passed by the inspecting officers.

The superstructure of the new Tay Bridge, no less than the piers, affords evidence of the provision which it is now thought necessary to make against the consequences of high wind pressures. Thus Mr. Barlow has provided three lines of defence against a train being hurled into the Tay, firstly, a guard balk of considerable height outside each rail; secondly, a ballasted floor of sufficient strength to hold up a derailed locomotive at any point; and thirdly, a strong iron parapet. Most of these provisions will in all probability be insisted upon by the Board of Trade in future railway bridges.

Turning now to the gigantic Forth Bridge, the influence of wind pressure in determining the design is beyond all precedent. The assumed lateral pressure of the wind upon the 1700 feet span girder is in fact no less than 50 per cent. greater than the maximum rolling load, so that were it not for the influence of gravity on the mass of the bridge, the required strength would be greater laterally than vertically to the extent of one-half. The weight of steel in the 1700 feet girder is, however, so considerable, that the stresses both for rolling load and wind pressure are relatively less than in smaller bridges.

The original design for the Forth Bridge by Sir Thomas Bouch was, it will be remembered, on the suspension principle. Except as regards the enormous drop in the suspension chains and the consequent unprecedented height of the piers, there was little to distinguish the proposed structure from an ordinary suspension bridge with stiffening girder, and without the inclined stays characteristic of American suspension bridges. During the past forty years the suspension principle has been universally rejected by engineers of all countries as unsuitable to the conditions of high-speed railway traffic, and the only reason for introducing it in the case of the Forth Bridge was the assumption that no other plan was commercially 


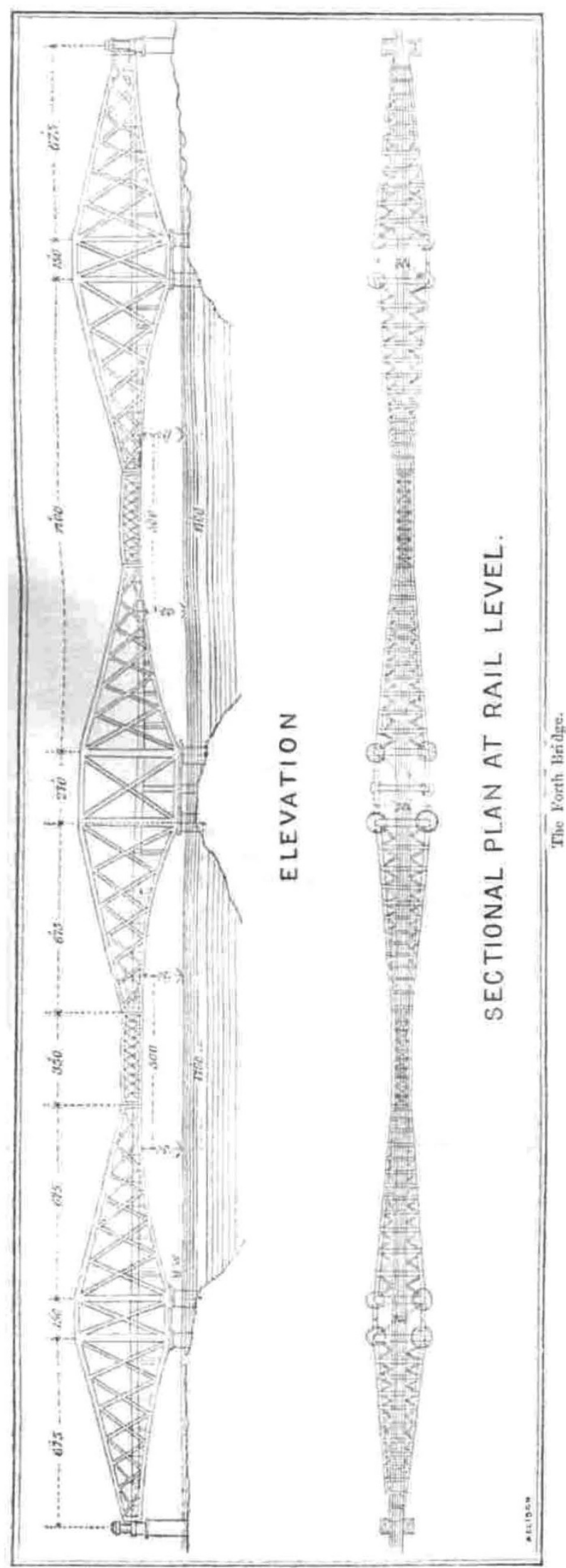

attainable. It caused no little surprise therefore, and not a few expressions of incredulity, when Messrs. Fowler and Baker announced that the span of 1700 feet was no reason at all for departing from the old and well-tested principle of girder construction, but that on the contrary a girder bridge of proper design would be not only infinitely stiffer, but also considerably cheaper, than a structure on the suspension principle. This conclusion was however confirmed by Mr. W. H. Barlow and Mr. T. E. Harrison after careful independent investigation, and a design was finally agreed upon by all the engineers and accepted by the four railway companies finding the funds for its construction.

The Forth Bridge as intended to be constructed may be briefly described as a continuous steel girder bridge, of varying depth and with fixed points of contrary flexure. In several essential points it is analogous to the wellknown continuous tubular girder bridge across the Menai Straits, as in both cases the continuous girder traverses two main spans and two end spans of about half the width of the former. In the Forth Bridge, however, the main spans are 1700 feet, and the end spans 675 feet, whilst in the Britannia Bridge the respective dimensions are but 460 feet and 230 feet. It is hardly necessary to say, therefore, that though the principle is the same the proportions and general details of the two structures present no points of resemblance.

The continuous girders of the Forth Bridge are 340 feet, or one-fifth of the span, in depth at the piers, and only 45 feet deep at the centre of the 1700 feet span. In ordinary continuous girders the points of contrary flexure are situated about one-fifth of the span from the piers, but in the Forth Bridge they are fixed at the most economical distance, which was found on investigation to be about two-fifths. Every continuous girder may, for purpose of calculation, be regarded as made up of a central girder supported by two cantilevers. In ordinary cases the central girder will have an effective span about equal to the total span $\div \sqrt{3}$. If the Forth Bridge were an ordinary continuous girder the effective span of the central girder would thus be about 982 feet, but as a matter of fact it will be made 350 feet, and it is to this deviation from the ordinary proportions that the economy of the design is largely due. By keeping the central girder of moderate span, or in other words by removing the points of contrary flexure farther from the piers, the central portion of the girder is lightened, the bending moment correspondingly reduced, and the mass of metal is concentrated near the piers, where it acts with the least leverage. Thus the lower member of the great girder, where it springs from the masonry piers at a height of 20 feet above high water, is a steel tube 12 feet diameter and about 2 inches thick, whilst at the centre of the span, where the bottom member has been cambered upwards to a height of 150 feet for navigation purposes, it is of ordinary trough section, about 3 feet in width.

On plan as well as in elevation the Forth Bridge is a continuous girder of varying depth. To resist high wind pressures the tubular lower members are spaced 120 feet apart, centre to centre at the piers, whereas the trough lower members of the central girder are spaced but 27 feet apart. By varying the effective depth of the girder both on plan and elevation a great saving is effected in the bracing, as the shearing stresses are to a large extent taken up by the main members of the girder. In a bowstring girder the bracing is similarly lightened by the arching of the top member. There are other sources of economy in the proposed design which we have not space to refer to at present.

It is intended, we understand, to give such proportions to the several members of the structure that under the combined stresses resulting from the maximum rolling load and a wind pressure of $56 \mathrm{lbs}$. per square foot, the stress per square inch will in no case exceed one- 
fourth of the ultimate strength of the steel used in construction. The steel used in compression will be considerably stronger and harder than the more ductile material used for the parts in tension.

Facility of erection has necessarily been one of the most important governing elements in the design of the Forth Bridge. With 200 feet depth of water, scaffolding is of course out of the question, and the only practicable way of erecting the great girders is by commencing the work at each pier and adding successive bays of struts, ties, and bracing on either side, until the whole structure is complete. This mode of erection, technically known as "erection by overbang," is that which has been successfully adopted in the two largest railway bridges yet constructed, namely, the St. Louis Bridge across the Mississippi, of 525 feet span, and the Douro Bridge, of the same span, near Lisbon. The great advantage and security of erection by overhang in a case like the Forth Bridge is that every piece of the work is finished and securely braced against storms before another length is commenced. When the bridge is partially finished it will at the distance present much the appearance of three huge birds perched with outspread wings on as many rocks. The distance between the tips of the wings will be represented by that between the ends of the cantilevers, or say, 1500 feet. It might be thought that this would be a critical stage of the erection, but it is not so, as the work is so designed that if a hurricare of $56 \mathrm{lbs}$. per square foot were to strike one wing whilst the other remained becalmed the cantilevers would not spin round like a weathercock, but remain perfectly stable and secure.

We understand that the Board of Trade have signified their approval of the design and i $f$ the provisions made by the engineers as rega rds strains and wind pressures.

\section{NOTES}

THE last work of the late $\mathrm{Mr} . \mathrm{H}$. C. Watson on the distribution of British plants was his "Topographical Botany," published in I873-4, in which he traced the dispersion of each species throngh the II 2 vice-counties of Britain which he adopted. Of this book only 100 copies were printed for private circulation, and these were all given away by the author immediately. Since its issue a large amount of new material has been accumulated, principally through the exertions of the members of the Botanical Record Club, and at the time of his death, last autumn, Mr. Watson was engaged in the preparation of a new edition. This he did not live to complete as regards its prefatory and explanatory portions, but he had kept an interleaved copy in which he regularly entered up every record of any plant in a new district that was brought to his notice. At his own special request this was deposited with his herbarium at Kew, and from this it is now proposed to prepare a second edition of the book, which Mr. Quaritch has undertaken to publish, and Mr. J. G. Baker, of the Royal Gardens, and the Rev. W. W. Newbould to make ready for the press.

THE New York Nation announces the death of Mr. Lewis H. Morgan at Rochester, N.Y., on December 17, after a brief illness following a long period of delicate health. "With reference to our pre-Columbian antiquities," the Nation states, "he might for some time past have been called the Nestor of Indian ethnologists. A native of Western New York, he early became interested in the neighbouring remnant of the once mighty Six Nations, and gained a thorough insight into the political and military constituti $n$ of the Coufederacy, its manners and customs, and above all its curious system of tribal intermarriages. Together with some kindred inquiring spirits he instituted, at the age of twenty-five, an Order, or 'New Confederacy' of the Iroquois-a sort of antiquarian society, having as a subsidiary aim the promotion of a kindlier feeling toward the red man; and before its 'councils' in the years 1844,5 , and 6 , he read a number of papers on the Iroquois, which, under the nom de plume of 'Skenandoak,' were published, as letters addressed to Albert Gallatin, in Cotton's American Quarterly Review, in 1847. From this source they were reprinted by Neville $B$. Craig, of Pittsburgh, in his monthly Olden Time (1848), and five years ago once more saw the light in Robert Clarke and Co.'s reprint of the latter periodical. This work at once put Mr. Morgan in the front rank of Indian authorities. A professional visit to Lake Superior led him to observe $e_{i}$ an animal closely associated with the aborigines, and toward the close of 1867 he produced the 'American Beaver and his Works,' an exhaustive but highly readable monograph, in which, to use the words of the late Jeffries Wyman (Nation, February 27, 1868), Mr. Morgan, "with a zeal and patience worthy of Réaumur, the Hubers, or of Darwin, re-examined the whole subject and largely increased our knowledge,' and which ' justly entitled him to an honourable place in the higher ranks of original observers.' The year following, in an article on the 'Seven Cities of Cibola,' in the North American Review (April, 1869), he struck a blow at the whole fabric of the theory of Indian civilisation handed down by the Spaniards and embalmed by Prescott, and laid the foundations of the prevailing conception of the meaning of that communal architecture which was for centuries regarded as royal and palatial. In 1873 appeared among the Smithsonian Institution's Contributions to Science a quarto volume of 700 pages, entitled 'Systems of Consanguinity and Affinity of the Human Family.' This was the first fruit of Mr. Morgan's discovery, while on his excursion to Lake Superior, that the system of marriage and relationship in the Six Nations was that of the American Indians generally, and his subsequent reflection that he had encountered a fundamental fact in the development of human society. He afterward resumed the whole question in a popular manner in his 'Ancient Society; or, Researches in the Line of Human Progress of Savagery through Barbarism into Civilisation.' His last work was among the pueblos of New Mexico, from the study of which be concluded that the Moundbuilders were village Indians of New Mexican origin, and that the mounds were the platforms for their long wooden communal houses. These conclusions were published in the first report of the Archæological Institute of America (1880). On his deathbed he received his very latest printed work, "Houses and House Life of the American Aborigines,' published by the Bureau of Ethnology of the Smithsonian Institution."

We regret to annource the death, at the age of seventy-one years, of Prof. J. W. Draper, of New York. We hope next week to give some account of his varied work in science. The death of Mr. Binney, of Manchester, is also announced, and of him also next week we shall give a brief memoir.

THE scientific circle in Dublin has sustained a great and a deeply felt loss by the sudden and premature death of Dr. Reuben J. Harvey. Reuben J. Harvey was born in 1845 ; he was the son of a well known physician in Cork, still living, and for many years one of the most distinguished professors in the Queen's College of that city. He entered Trinity College, Dublin, in 1863, obtaining a non-foundation schclarship in science in 1866 ; he graduated as a senior gold medallist (Mathematical Tripos) in $186 \%$. Entering the medical school of the University of Dublin be obtained the first medical scholarship in 1868 , and graduated as M.B. in 1870 . He completed his studies in the schools of Vienna and Wurzburg; at one time he was a demonstrator in anatomy in the Dublin University School; of late years he was Professor of Physiology in the Carmichael School of Medicine, and one of the physicians of the Cork Street Fever Hospital. In the pursuit of his professional duties he was taken ill of typhus fever on the 24th of December last, of which he died on the 28th of the same month. His sterling qualities 